\title{
Leaving Parental Home in Selected Central European Countries
}

\author{
LUCIE KYNČILOVÁ \\ Charles University in Prague, Faculty of Science, \\ Department of Demography and Geodemography
}

\begin{abstract}
The article examines leaving parental home in selected Central European countries: The Czech Republic, Poland and former German Democratic Republic. Women born in 1952-1972/1982 were analysed. The topic is first discussed theoretically and conceptually. It gives the basic overview of the life course perspective and of the concept of transition to adulthood. The Fertility and Family survey data were analysed using survival analysis. The aim of the study is timing of leaving parental home and analyzing the predictors of leaving parental home. Although the Central European countries did not offer extreme differences in demographic behaviour, specific similarities and differences in timing, especially in predictors of leaving home, had been expected and found afterwards.
\end{abstract}

Key words: transition to adulthood - leaving home - life course - Central Europe - survival analysis

\section{Introduction}

Transition to adulthood, especially leaving parental home, considered here as a part of the life course perspective, attracted interest of demographers particularly at the beginning of the 1990's. Changes in reproductive and family behaviour that have occurred since 1960 have caused increasing interest in the concept of transition to adulthood. Economic, institutional and cultural interactions set up a new long-term unpredictable process of becoming an adult. It was not a short-term time period with well-defined phrases anymore, but much more heterogeneous period of life course.

I wanted to analyse leaving parental home in Central Europe in the second half of the $20^{\text {th }}$ century. Changes of the transition to adulthood were not perceptible in that region at that time. Selected countries: The Czech Republic, Poland and the former East Germany did not show so much diversity signs at the first sight. Notwithstanding, similarities and differences have been explored.

The Czech Republic, Poland and East Germany belonged to the former socialist bloc. When analysing transition to adulthood in these countries, adopting a cau- 
tious approach is advisable. The 1950s-1970s birth cohorts experienced their transition to adulthood in the context of socialist family and social policy. Two assumptions can be made. Firstly, similar development of transition to adulthood might be observed due to the same political system that governed cultural and economical development of these countries for 40 years. Secondly, selected countries have retained their cultural-historical patterns in spite of all restrictions made by the communist government. Above mentioned aspects influencing people's lives can be divided into two groups, there are institutional factors on the one hand and long-term cultural-historical development of a given country on the other hand.

In this paper, patterns of transition to adulthood in selected Central European countries are explored. Cohort data from Fertility and Family Survey (FFS) were used to examine the timing of leaving home and synchronizing and sequencing of several events in the transition to adulthood. The aim of the study is three-fold: First, to analyze particular factors in selected countries separately and find their influence on leaving parental home. The second emphasis is on the comparison of timing of leaving parental home in the Czech Republic, Poland and former East Germany. Finally, the third aim is to focus on the relationship between selected events in the transition to adulthood in terms of leaving parental home.

\section{Theoretical framework}

Transition to adulthood is considered as one of the crucial events in life course perspective. It is very often represented by the end of co-residence between children and parents and the establishment of an independent living (White 1994). Determinants of transition to adulthood vary throughout the scientific literature. Among the essential determinants of transition to adulthood is considered the end of education, first employment, leaving parental home, first partnership formation (first marriage) and birth of a first child (White, Lacy 1997). According to different researchers, not all of the above mentioned determinants are considered as the key determinants (Ibid.). They mention that the process of leaving home was put aside and not examined as a part of the transition to adulthood. At the present time, leaving home is considered as one of the crucial parts of the transition to adulthood (Billari 2000), (Iacovou and Berthoud 2001), (Huinink, Konietzka 2000).

Iacovou and Berthoud discuss conception of youth. They define it (Iacovou, Berthoud 2001) as follows: "Although childhood and adulthood are recognizably defined, the years in between are years where the life course is increasingly diverse: where transitions in the sphere of the family and the labour market are multiple and reversible, and less likely to occur in an orderly fashion." So, although the state of childhood and adulthood are well defined, the transition from one phase of life to the other cannot be determined with precision.

The timing of events plays a substantial role in the life course. Besides age and timing, other approaches give us evidence about the circumstances of leaving pa- 
rental home. The process of leaving parental home is interconnected with other processes of transition to adulthood that might influence the event of leaving parental home itself. "The order of events in transition to adulthood is a key issue."1 Billari (2001) presents other eventual measures that help to find connection between processes and transitions in the transition to adulthood. Those are synchronisation and sequencing.

There are differences in leaving parental home between different societies. In some societies, the process of leaving parental home is directly connected with getting married. On the contrary, in some societies young people gain their independence before they start to form their own families.

No less important issue is related to processes and factors that might have influence on the transition to adulthood, in other words on the event of leaving parental home. The timing of events is the result of interacting factors, both personal and institutional (Corijn 2001). Juang (1999) talks about interaction of several factors as well. She adds a comment connected with Bronfenbrenner's ecological systems theory of development, which describes the effects of the factors that make for the timing of leaving the parental home: "An individual is embedded in multiple contexts, ranging from the most intimate (microsystem) to the most distal (the macrosystem and chronosystem)." Most of the studies focus on macro-level factors. Aassve (2001) divides these factors between institutional (socio-economic) and long-term cultural. First group of factors relate mostly to macrosocial and economic changes that have constrained the policy makers in creating institutional domain by e.g. family, social, housing and fiscal policy. Second group of factors is defined as long-term cultural and historical path-dependencies that shaped present basic differences of young people's behaviour patterns at the societal level. Basic differences are set between west and east European families known as Hajnal line. That imaginary line runs from St. Petersburg in Russia to Trieste in Italy and divides historic family systems (Billari 2004). To the west of the line, the typical patterns of family formation were late marriage, neo-local nuclear family and early leaving parental home. On the other hand, to the east of the line, people were getting married very early and standard families used to be quite extended.

There is a reasonable explanation for the increased interest in the transition to the adulthood studies in the last 15-20 years. The process of transition to adulthood has gone through numerous changes. The well-defined series of events that usually meant leaving the parental (orientational) home to newly created (generational) family is not valid anymore. This transition was usually connected with getting married.

Trying to grasp these societal changes, Corijn (2001) presents basic principles of the second demographic transition that was defined by van de Kaa for the period around 1960's in Western Europe. According to Corijn the basic principles are:

Billari, 2001, p. 3. 
socio-economic changes in society, cultural changes and technological progress. Above mentioned changes had mainly influenced young generation. The period of transition to adulthood had become diversified. The diversity is definitely challenging for researchers, who find Europe an outstanding field for analysis.

In the period that is examined, Central Europe could not provide such an appealing field for investigation of the transition to adulthood as Western Europe. I am aware that the major societal changes have happened after the fall of the Iron Curtain. So, young people that entered the adulthood in 90's will certainly become very interesting object for researchers. Nevertheless, process of becoming an adult is crucial in every society and in every period of time. The likelihood that adult children will reside in parent's house is declining with parent's and children's age. Children start to gain their socio, economic and cultural independence at the age of becoming an adult (Huinink, Konietzka 2000). Due to specific (above mentioned) cultural path-dependencies, I definitely find it interesting to follow the timing of leaving home in selected countries before the societal and economic transition.

\section{Data and Methodology}

\section{Data}

The data were used from the series of Fertility and Family Survey (FFS) that was mainly conducted in the 90's. The FFS was co-ordinated by the Population Activities Unit of the Economic Commission for Europe of the United Nations. The survey was designed to provide not only basic information about demographic behaviour in selected countries, but to gain respondents'opinions and attitudes as well. Independent sample of women and men was obtained in most of the countries with some exceptions, the Czech Republic among them. In the Czech Republic couples were included in the FFS, contrary to the programme guidelines (Festy, Prioux 2002). Therefore, the sample of men was not independent. On this account, to preserve comparability, only women's samples were used in the analysis. Surveys in selected countries were carried out in December 1991 (Polish FFS), September 1992 (East German FFS) and December 1997 (Czech FFS). The fact, that the fieldwork was spread over a long period, led to the acceptance of specific approaches in order to make the analysis possible (see below "Comments to methodology and using statistical methods").

\section{Methods}

The concept of survival analyses was used in this study. The centre of the analysis is an individual or a group of individuals that are experiencing an event (study event) after a certain period (survival time). Survival analysis should give us the explanation why some individuals have higher probability to experience the event 
than the others and what factors influence the survival time of a given individual. The analysis can be described as an analysis of the duration of the non-occurrence of an event during the risk period (Vermunt, Moors).

The event of interest (failure events) is given by specifying the research question. Here, in the study, the event is "leaving parental home".

Timing of the event was examined by calculating Kaplan-Meier estimates of the survivor functions and by life table method. Estimated median ages and estimated value of the survivor functions for leaving home were used for describing the situation.

Semi-parametrical model, the Cox regression, was used in order to analyze the effect of selected risk factors on survival.

The Variables

I studied the transition to leaving parental home. The length of being at the parent's home was set as a dependent variable. I used retrospective event histories given by respondents. The key question was: "In which month and year did you leave your parents or fosters to live independently?"

Other variables were used or created in order to allow more detailed analysis. They are: cohorts, religion, divorce of parents, numbers of siblings, residence and education.

Comments on methodology and using statistical methods

In order to achieve international comparison, two steps in data layout were done. First, it is necessary to have the same cohorts in the sample. Hence, the analysis of the FFS data was restricted to the data of women born between 1952-1972. Second, cohorts have to be exposed to the risk for the same period of time. The survey was conducted in different years, so East German and Czech data were set to the same year as the Polish data, i.e. December 1991. In this manner, all of the women were able to experience a particular event during the same time, during the same risk period.

Missing and incorrect (if a year was not provided) data relating to leaving parental home were excluded from the study. If a month was not provided in the data set, half year was utilized for the analysis.

\section{Education}

Applying the variable "education" in the analysis included some difficulties. There are more options how to approach to the variable "education", three ways are discussed in the study. The first possibility was to use the highest educational level of women in the sample, at the time of the survey. This kind of approach was not used for two reasons. We needed the information about educational level at the 
time of leaving parental home, especially because of the second part of the analysis, where women from selected countries were compared. The risk period was modified (see above), so it is not possible to work with fixed data. The second reason is the quality of the variable defined like this by itself. Hamplová (2001) mentions that in terms of education the dependent variable is more effected by the status of the interviewee (student $\mathrm{x}$ graduate) than by the highest degree. So, this approach was rejected. Second, the variable "education" can be represented as a time-varying covariate to control for "educational enrolment". The data about the end of education (a year and a month) and the highest degree of education are available. On the basis of these data, it could be possible to construct binary time-varying covariates which define the period when a woman is still studying (being in education) and then when she has finished her studies (out of education). Firstly, this approach is rather simplifying. Secondly, there were problems with creating this variable in different statistic programs than the other variables. Nevertheless, this variable, education as a time-varying covariate, has been used as complementary. Third possibility is to analyse educational attainment at the time when women left parental home. The variable is an estimation of educational attainment at the time of leaving parental home based on knowledge about the educational system of the given country. The system of creating the estimation is explained further. I have worked with the year and month when women finished their education. Next, new variable was created: "leaving parental home". I have coded the information according to the fact whether the women finished education before or after leaving home. I have coded the same highest degree that the women stated in the survey when they finished their education first and then left home. When they stated that they had left parental home before finishing their education, education attainment was estimated in accordance with the year that is typical for attainment of the particular degree of education.

The third approach "educational attainment" was used in both parts of the analysis; the second approach "educational enrolment" was applied as a complementary in the first part (analysis of given state separately).

\section{Patterns of leaving parental home: timing}

The analysis of timing of leaving parental home was carried out firstly for each state separately and secondly for all three countries together, so comparison was made. There are differences between these parts in the methodology (see above "Comments on methodology and using statistical methods").

Figures and result are first described by estimated survival function that illustrates the cumulative proportion of non-occurrence of the event during the risk period. Next, estimated median ages are presented and finally, I report the relative risk of leaving parental home depending on different factors. 


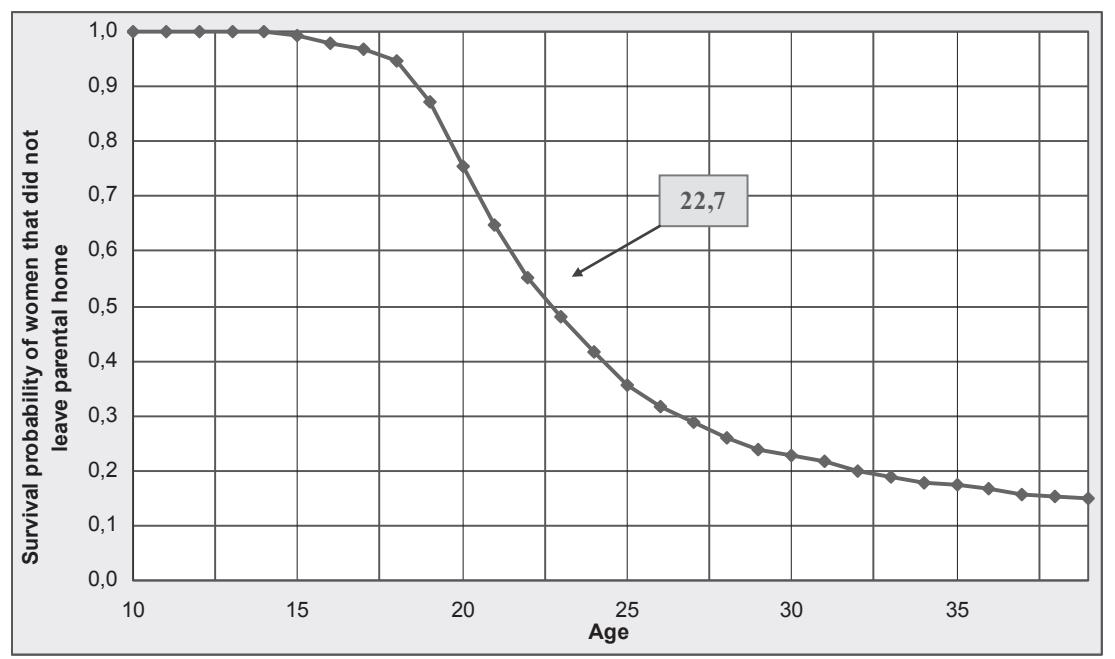

Fig. 1 Survival probability of women that did not leave parental home, Poland Source: Author calculation based on Polish FFS data.

Timing: leaving parental home in Poland

Women born in the period 1952-1972 were involved in the analysis. Nearly one third of all cases were right censored.

The graph (Figure 1) above presents the survival function of leaving parental home in Poland. The estimated survival function shows that after the $18^{\text {th }}$ birthday the curve falls rapidly. One of the matters of interest is that the curve has a steadily falling tendency. The median age of leaving home is 22.7 . Nearly $15 \%$ of women have never left parental home. Due to this fact it can be claimed that Poland belongs to the South-European pattern of leaving home (see Billari 2001; Sienkiewicz 2003).

Almost all of the variables made the requirements for statistical significance except of "religion" and "divorce of parents". Variables that were statistically significant entered the Cox proportional hazard model to find out the influence on probability of leaving parental home. At first, model with only one explanatory variable is introduced (see Table 1).

The results reveal that in the Polish sample there is a strong effect of number of siblings, region and education. The more siblings the women had, the higher probability of leaving parental home there was. Living in the urban area meant delaying of leaving parental home. As I mentioned before, there are more approaches to creating the education variable. The first (educational enrolment) says that studying women had lower probability of leaving parental home than women that had already graduated. The second (educational attainment) signifies that lower degree of education accelerates home leaving. 
Tab. 1 Model: relative risk of leaving parental home, one explanatory variable, Poland

\begin{tabular}{|l|c|c|}
\hline Factors & sign. & Exp (B) \\
\hline Number of siblings & $* * *$ & 1.146 \\
\hline Region & $* * *$ & 0.800 \\
\hline Cohorts & $*$ & 0.865 \\
\hline Education (educ. enrolment) & $* * *$ & 1.141 \\
\hline Education (educ. attainment) & $* *$ & 0.491 \\
\hline
\end{tabular}

Note: $* \mathrm{p}<0.05 ; * * \mathrm{p}<0.01 ; * * * \mathrm{p}<0.001$.

Source: Author calculation based on Polish FFS 1991 data.

Tab. 2 Model: relative risk of leaving parental home, more explanatory variables, Poland

\begin{tabular}{|c|c|c|c|c|c|c|c|c|}
\hline \multirow[b]{2}{*}{ Factors } & \multicolumn{8}{|c|}{ Model } \\
\hline & $\operatorname{Exp}(B)$ & sign. & $\operatorname{Exp}(B)$ & sign. & $\operatorname{Exp}(B)$ & sign. & $\operatorname{Exp}(B)$ & sign. \\
\hline \multicolumn{9}{|l|}{ Cohorts } \\
\hline $1952-1962$ & ref. & & ref. & & ref. & & ref. & \\
\hline $1963-1972$ & 0.865 & $*$ & 0.871 & $*$ & 0.886 & & 0.901 & \\
\hline \multicolumn{9}{|l|}{ Region } \\
\hline Rural & & & ref. & & ref. & & ref. & \\
\hline Urban & & & 0.803 & $* * *$ & 0.846 & $* * *$ & 0.850 & $*$ \\
\hline \multicolumn{9}{|l|}{ Siblings } \\
\hline 0 sibling & & & & & 0.763 & $*$ & 0.803 & $*$ \\
\hline 1 sibling & & & & & ref. & & ref. & \\
\hline 2 siblings & & & & & 1.108 & & 1.019 & \\
\hline 3 and more siblings & & & & & 1.204 & $* *$ & 1.014 & \\
\hline \multicolumn{9}{|l|}{ Education } \\
\hline Primary & & & & & & & ref. & \\
\hline Secondary & & & & & & & 0.602 & $* * *$ \\
\hline Tertiary & & & & & & & 0.378 & $* * *$ \\
\hline Log-likelihood & \multicolumn{2}{|c|}{-13740.31} & \multicolumn{2}{|c|}{-13728.93} & \multicolumn{2}{|c|}{-13717.81} & \multicolumn{2}{|c|}{-13597.12} \\
\hline
\end{tabular}

Note: $* \mathrm{p}<0.05 ; * * \mathrm{p}<0.01 ; * * * \mathrm{p}<0.001$.

Source: Author calculation based on Polish FFS 1991 data.

The second model I present here is the model with all the variables (see Table 2). It is evident that after adding more explanatory variables to the model, the previous predictors start to be less significant. Education is the factor with the strongest effect. At the end (except education) only women without siblings and women living in the urban area are statistically significant. These two groups of women have a $20 \%$ less probability to leave home than women with more siblings/women from the rural area.

Timing: leaving parental home in East Germany

The sample of women born in the period 1952-1972 was used for the analysis. Nearly $10 \%$ of cases were censored; it concerns the women that had not left home before the time of the survey. 


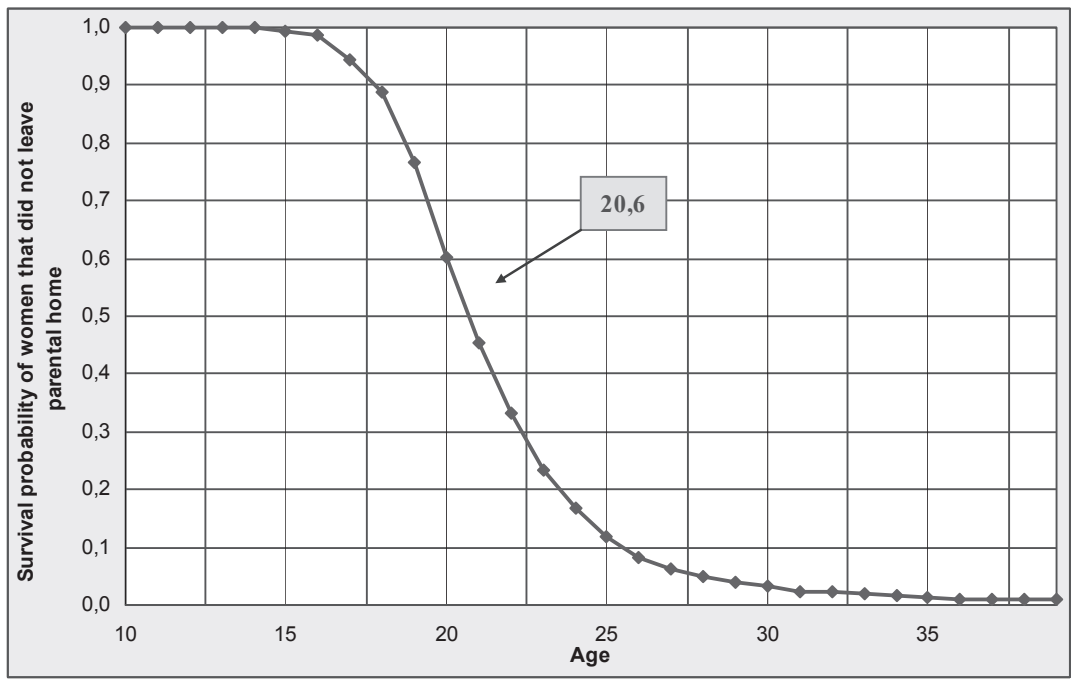

Fig. 2 Survival probability of women that did not leave parental home, East Germany Source: Author calculation based on German FFS data.

The graph below (Figure 2) presents the estimated survival function of leaving parental home. Similarly as in the Polish case, the estimated survival function of East German sample falls rapidly after the age of 18. In the case of East Germany we speak about very sharp fall until the age of 25 . Almost $90 \%$ of all women left parental home at that age. The median age of leaving home is 20.6. This fact indicates the move of East Germany to the north-European family patterns. Billari (2001) states that almost all of the women in Northern and Western Europe leave their home by the age of 30 .

Next step of the analysis was to find out statistically significant variables. It was realized that the divorce of parents, number of siblings, religion and education can enter the model. The homogeneity test proved that variables - region and cohorts have statistically insignificant influence on the decision about leaving parental home. The relative risk for above mentioned statistically significant variables is illustrated below (Table 3).

The model for only one explanatory variable indicates that all of the four variables separately have a strong influence on parental home leaving in East Germany. The relative risk of leaving parental home is significantly higher for those whose parents separated ( $28 \%$ higher risk of leaving parental home), who have more siblings ( $11 \%$ higher risk) and who are not believers ( $22 \%$ higher risk). The final variable considered here is education. Two approaches are introduced again. First, education as a time-varying variable; those studying remain in the parental home longer. Second, education as a fixed variable; the estimation at the time of leaving parental home implies that those having higher educational attainment stayed at home longer than those having lower degree. 
Tab. 3 Model: relative risk of leaving parental home, one explanatory variable, East Germany

\begin{tabular}{|l|c|c|}
\hline Factors & sign. & Exp (B) \\
\hline Divorce of parents & $* * *$ & 1.279 \\
\hline Religion & $* * *$ & 1.220 \\
\hline Number of siblings & $* * *$ & 1.114 \\
\hline Education (educ. enrolment) & $* * *$ & 1.265 \\
\hline Education (educ. attainment) & $* * *$ & 0.450 \\
\hline
\end{tabular}

Note: $* \mathrm{p}<0.05 ; * * \mathrm{p}<0.01 ; * * * \mathrm{p}<0.001$.

Source: Author calculation based on German FFS 1992 data.

Tab. 4 Model: relative risk of leaving parental home, more explanatory variables, East Germany

\begin{tabular}{|c|c|c|c|c|c|c|c|c|}
\hline \multirow[b]{2}{*}{ Factors } & \multicolumn{8}{|c|}{ Model } \\
\hline & $\operatorname{Exp}(B)$ & sign. & $\operatorname{Exp}(B)$ & sign. & $\operatorname{Exp}(B)$ & sign. & $\operatorname{Exp}(B)$ & sign. \\
\hline \multicolumn{9}{|l|}{ Divorce of parents } \\
\hline Separated & 1.279 & $* * *$ & 1.258 & $* *$ & 1.273 & $* * *$ & 1.21 & $* *$ \\
\hline Not separated & ref. & & ref. & & ref. & & ref. & \\
\hline \multicolumn{9}{|l|}{ Religion } \\
\hline Believers & & & 0.653 & $* * *$ & 0.638 & $* * *$ & 0.587 & $* * *$ \\
\hline Non-believers & & & ref. & & ref. & & ref. & \\
\hline \multicolumn{9}{|l|}{ Siblings } \\
\hline 0 sibling & & & & & 0.822 & $* *$ & 0.804 & $* * *$ \\
\hline 1 sibling & & & & & ref. & & ref. & \\
\hline 2 siblings & & & & & 1.179 & $* *$ & 1.117 & \\
\hline 3 and more siblings & & & & & 1.132 & $* *$ & 1.021 & \\
\hline \multicolumn{9}{|l|}{ Education } \\
\hline Polyt. educ. & & & & & & & ref. & \\
\hline Tertiary educ. & & & & & & & 0.540 & $* * *$ \\
\hline Log-likelihood & \multicolumn{2}{|c|}{-17127.1} & \multicolumn{2}{|c|}{-17113.7 } & \multicolumn{2}{|c|}{$\frac{1}{-17095.1}$} & \multicolumn{2}{|c|}{-16853.1} \\
\hline
\end{tabular}

Note: $* \mathrm{p}<0.05 ; * * \mathrm{p}<0.01 ; * * * \mathrm{p}<0.001$.

Source: Author calculation based on German FFS 1992 data.

Results of the one-explanatory variable model were strengthened in the second model where all variables were included. Contrary to the Polish model, here all the variables remained quite strong even after other variables were added to the model (Table 4).

Timing: leaving parental home in the Czech Republic

The analysis of the Czech Republic distinguishes partly from the others. For the reason that the Czech FFS was held in 1997, the sample of women born in the period 1952-1982 was included in this part of the study. The sample of Czech women contains $24 \%$ of censored cases which is most likely given by the group of youngest women born in 1972-1982. It is necessary to take into account that women in the Czech sample have experienced the period of transformation of society. It is assumed that there will be some differences between these women and the others in 
the timing of leaving parental home. On the other hand, all the women from the sample grew up in the communist regime, so it is not expected that all the changes in family patterns would be in such evidence.

At first, an analysis without explanatory variables was executed. The estimated survival function is presented below (Figure 3).

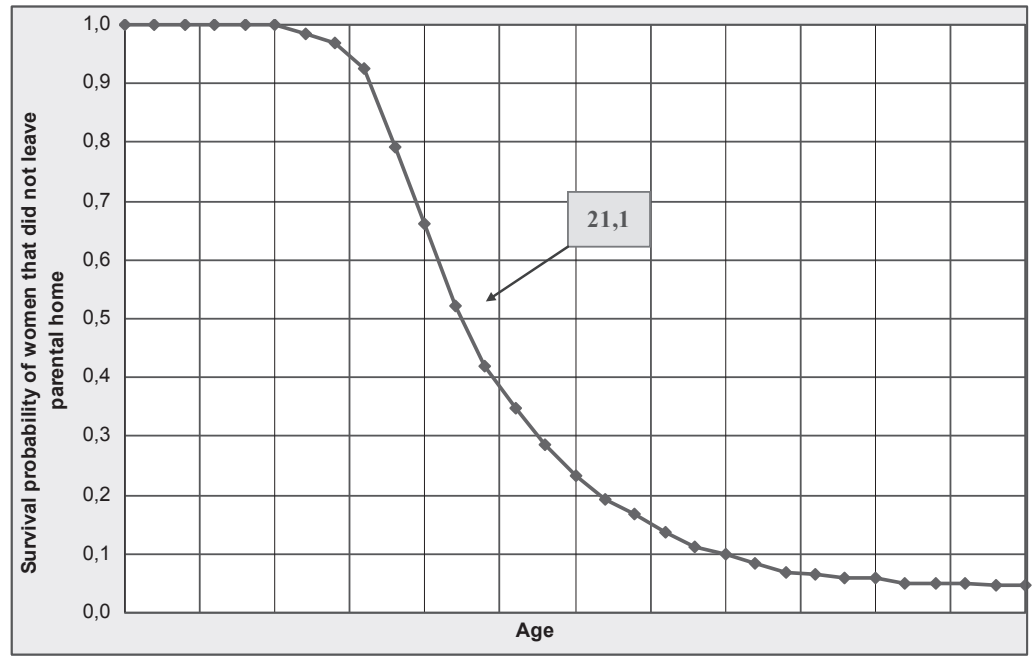

Fig. 3 Survival probability of women that did not leave parental home, Czech Republic Source: Author calculation based on Czech FFS data.

The curve falls rapidly after the age of 18 . The slope of the curve is nearly as sharp as the East German example, but fewer women left by the age of 25 . The median age of home leaving is 21 , which means that half of the women from the sample left home at the age of 21.

Identically as in previous cases, Cox proportional hazard model for oneexplanatory variable was computed. Statistical significant variables - cohorts, number of siblings, divorce of parents, religion and education - entered the model (see Table 5).

All the variables have quite a strong influence on parental home leaving, except religion. Not surprisingly, significant factors of cohorts influence the risk of leaving parental home. The youngest women (born in 1972-1982) had lower probability to leave home than the older women. Next, women who had fewer siblings and parents living together stayed at home longer than the others.

Two approaches of presenting the variable education show the same aspects as in the two previous examples. First, education as a time-varying variable proved that women in educational process have lower risk of leaving home. Second, estimation at the time of leaving parental home implies that those who had a higher educational attainment stayed at home longer than those with a lower degree. 
Tab. 5 Model: relative risk of leaving parental home, one explanatory variable, Czech Republic

\begin{tabular}{|l|c|c|}
\hline Factors & sign. & Exp (B) \\
\hline Cohorts & $* *$ & 0.881 \\
\hline Number of siblings & $* * *$ & 1.214 \\
\hline Divorce of parents & $* * *$ & 0.693 \\
\hline Education (educ. enrolment) & $* * *$ & 1.260 \\
\hline Education (educ. attainment) & $* * *$ & 0.651 \\
\hline
\end{tabular}

Note: $* \mathrm{p}<0.05 ; * * \mathrm{p}<0.01 ; * * * \mathrm{p}<0.001$.

Source: Author calculation based on Czech FFS 1997 data.

Tab. 6 Model: relative risk of leaving parental home, one explanatory variable, Czech Republic

\begin{tabular}{|c|c|c|c|c|c|c|c|c|c|c|}
\hline \multirow[b]{2}{*}{ Factors } & \multicolumn{10}{|c|}{ Model } \\
\hline & $\operatorname{Exp}(B)$ & sign. & $\operatorname{Exp}(B)$ & sign. & $\operatorname{Exp}(B)$ & sign. & $\operatorname{Exp}(B)$ & sign. & $\operatorname{Exp}(B)$ & sign. \\
\hline \multicolumn{11}{|c|}{ 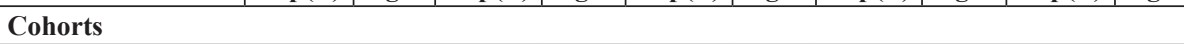 } \\
\hline $1952-1962$ & ref. & & ref. & & ref. & & ref. & & ref. & \\
\hline 1963-1972 & 0.973 & & 0.957 & & 0.960 & & 0.974 & & 0.981 & \\
\hline 1973-1982 & 0.723 & $* *$ & 0.715 & $* *$ & 0.712 & $* *$ & 0.735 & $* *$ & 0.715 & $* * *$ \\
\hline \multicolumn{11}{|l|}{ Religion } \\
\hline Believers & & & 0.952 & & 0.956 & & 0.865 & & 0.872 & \\
\hline Non-believers & & & ref. & & ref. & & ref. & & ref. & \\
\hline \multicolumn{11}{|l|}{ Divorce of parents } \\
\hline Separated & & & & & 1.428 & $* * *$ & 1.425 & $* * *$ & 1.356 & $* * *$ \\
\hline Not separated & & & & & ref. & & ref. & & ref. & \\
\hline \multicolumn{11}{|l|}{ Siblings } \\
\hline 0 sibling & & & & & & & 0.854 & & 0.889 & \\
\hline 1 sibling & & & & & & & ref. & & ref. & \\
\hline 2 siblings & & & & & & & 1.187 & & 1.119 & \\
\hline 3 and more siblings & & & & & & & 1.413 & $* * *$ & 1.413 & $* * *$ \\
\hline \multicolumn{11}{|l|}{ Education } \\
\hline Primary & & & & & & & & & 1.354 & $* * *$ \\
\hline Secondary & & & & & & & & & ref. & \\
\hline Tertiary & & & & & & & & & 0.671 & $* * *$ \\
\hline Log-likelihood & \multicolumn{2}{|c|}{-8562.5} & \multicolumn{2}{|c|}{-8553.9} & \multicolumn{2}{|c|}{-8542.4} & \multicolumn{2}{|c|}{-8522.6} & \multicolumn{2}{|c|}{-8484.6} \\
\hline
\end{tabular}

Note: $* \mathrm{p}<0.05 ; * * \mathrm{p}<0.01 ; * * * \mathrm{p}<0.001$.

Source: Author calculation based on Czech FFS 1997 data.

When all the variables are included in one model (see Table 6) very similar results are obtained as in the model of one-explanatory variable.

None the less, the effect of education is the strongest. Those who attained primary education had a 35\% higher risk of leaving home, while those attained the tertiary education had a $33 \%$ lower risk of leaving parental home. The effect of number of siblings, divorce of parents and cohorts is strong as well. The hypothesis that the relative risk of leaving parental home by the youngest cohort will be different has been approved. 
The main purpose of this part of the study is to compare timing of parental home leaving in the three countries in one model. On that account, data for this part was methodologically modified (see "Data and Methodology").

Comparison by means of interquartile range can appear slightly simplified, but straightforward. This kind of descriptive statistics can show us how the process of leaving parental home is homogeneous or heterogeneous. In the Czech Republic the value of interquartile range is 4.3; in East Germany it is 3.8 and in Poland the value is 8.4. It is obvious that in the Czech Republic and East Germany the process of home leaving is homogenous, while in Poland quite heterogeneous. The values of all main quartile are presented below (Table 7).

Estimated survival functions give us more complex view of the matter of leaving parental home in the three selected countries (see Figure 4).

Tab. 7 Quartiles, leaving parental home, Czech Republic, Poland, East Germany

\begin{tabular}{|l|c|c|c|}
\hline Country & Q1 & Q2 & Q3 \\
\hline Czech Republic & 19.1 & 20.9 & 23.4 \\
\hline Poland & 20.0 & 22.7 & 28.4 \\
\hline East Germany & 19.1 & 20.6 & 22.8 \\
\hline
\end{tabular}

Source: Author calculation based on Polish, Czech and German FFS data.

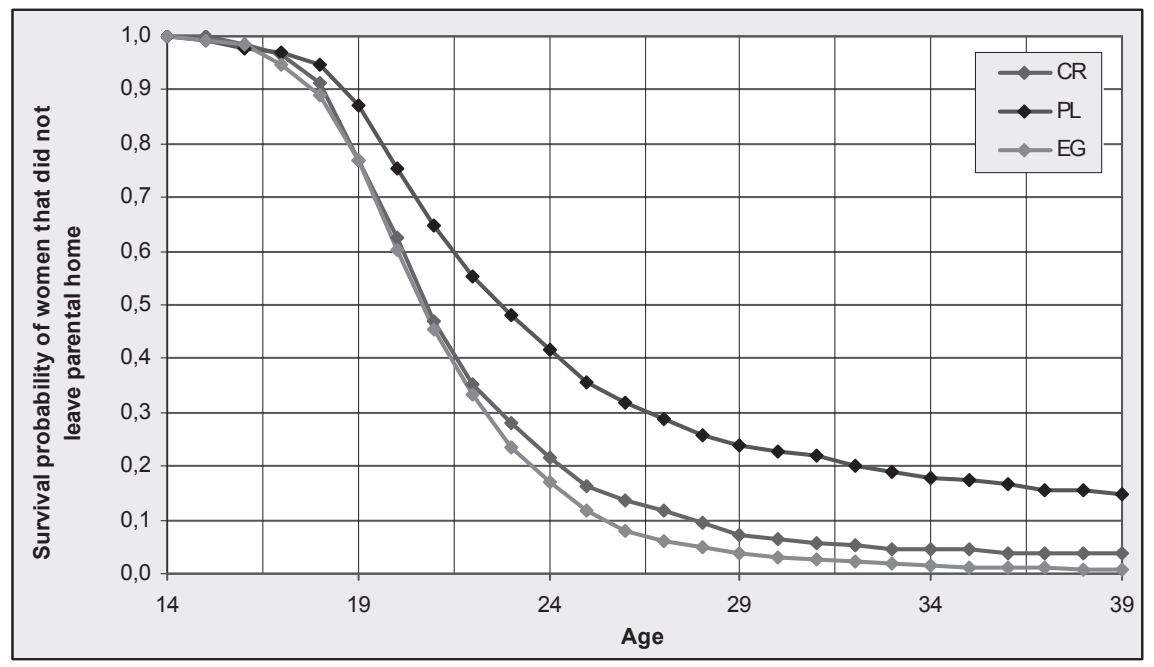

Fig. 4 Survival probability of women that did not leave parental home, Czech Republic, Poland and East Germany

Source: Author calculation based on Polish, Czech and German FFS data. 
The courses of all three functions are quite identical, though some differences are noticeable. The cumulative probability of staying at parental home in Poland is the highest of all the countries. On the contrary, the cumulative probability of staying at parental home in East Germany was the lowest for the whole period. The very sharp decline after the age of 18 is evident in every country, but slope and the continuation differ. While the share of women that had left parental home by the age of 18 did not differ so markedly among countries, the differences between countries, especially between Poland on one side and East Germany and the Czech Republic on the other side, were very distinct at the age of 25 . The consequence of this development is the share of women that never left home (at the age of 39) (see Figure 4).

In the next step, the analysis of all the explanatory variables proceeded to intercept what differences there are between the influences of particular variables on parental home leaving. The homogeneity test has confirmed that all the variables are statistically significant.

Firstly, for better notion of what the influence of one particular variable on parental home leaving in all countries was, one-variable model was created (see Table 8, Model A1-6). The general patterns show that in every one-variable model the relative risk of leaving parental home in Poland is the lowest. One of the findings is that the effect of every variable is rather high, which is why I explain the effect on leaving parental home by only one variable.

Secondly, as joint model was created (see Table 8, Model B). All the countries and all the explanatory variables were included. The aim of this step was to find out which variable has the strongest effect on leaving parental home in all three countries. The advantage of this joint model is that it helps to control the interactions and possible correlation of all the explanatory variables all at once. Compared to the model with only one explanatory variable, there is a very low probability that some other explanatory variable effects latently selected variables. The results of relative risk are presented above (Table 8). One of the important findings is that the values of the hazard ratio in Poland are below one without exception. On the contrary, the values for the relative risk of leaving parental home in East Germany are above one in most cases.

Tab. 8 Final model: relative risk of leaving parental home, all explanatory variables, Czech Republic, Poland, East Germany

\begin{tabular}{|l|c|c|c|c|}
\hline & \multicolumn{2}{|c|}{ Model A 1-6 } & \multicolumn{2}{c|}{ Model B } \\
\hline Factors & $\operatorname{Exp(B)}$ & sign. & $\operatorname{Exp(B)}$ & sign. \\
\hline Cohorts & ref. & & ref. & \\
\hline CR_1952-1962 & 1.023 & & 1.046 & \\
\hline CR_1963-1972 & 0.591 & $* * *$ & 0.370 & $* * *$ \\
\hline PL_1952-1962 & 0.530 & $* * *$ & 0.348 & $* * *$ \\
\hline PL_1963-1972 & 1.149 & $*$ & 0.961 & \\
\hline EG_1952-1962 & 1.164 & $* *$ & 0.989 & \\
\hline EG_1963-1972 & & & & \\
\hline
\end{tabular}




\begin{tabular}{|c|c|c|c|c|}
\hline & \multicolumn{2}{|c|}{ Model A 1-6 } & \multicolumn{2}{|c|}{ Model B } \\
\hline Factors & $\operatorname{Exp}(\mathbf{B})$ & sign. & $\operatorname{Exp}(B)$ & sign. \\
\hline \multicolumn{5}{|l|}{ Region } \\
\hline CR_rural & ref. & & ref. & \\
\hline CR_urban & 1.038 & & 1.109 & \\
\hline PL_rural & 0.653 & $* * *$ & 0.373 & $* * *$ \\
\hline PL_urban & 0.519 & $* * *$ & 0.348 & $* * *$ \\
\hline EG_rural & 1.059 & & 0.853 & \\
\hline EG_urban & 1.198 & $* *$ & 0.989 & \\
\hline \multicolumn{5}{|l|}{ Religion } \\
\hline CR_non-believers & 0.981 & & 0.885 & \\
\hline CR_believers & ref. & & ref. & \\
\hline PL_believers & 0.537 & $* * *$ & 0.451 & \\
\hline PL_non-believers & 0.561 & $*$ & 0.724 & $* *$ \\
\hline EG_believers & 0.756 & & 0.730 & \\
\hline EG_non-believers & 1.145 & $*$ & 1.137 & \\
\hline \multicolumn{5}{|l|}{ Number of siblings } \\
\hline CR_0 siblings & 0.819 & & 0.856 & \\
\hline CR_1 sibling & ref. & & ref. & \\
\hline CR_2 siblings & 1.137 & & 1.115 & \\
\hline CR_3 and more siblings & 1.550 & $* * *$ & 1.427 & $* * *$ \\
\hline PL_0 siblings & 0.431 & $* *$ & 0.267 & $* * *$ \\
\hline PL_1 sibling & 0.561 & $* * *$ & 0.343 & $* * *$ \\
\hline PL_2 siblings & 0.631 & $* * *$ & 0.352 & $* * *$ \\
\hline PL_ 3 and more siblings & 0.710 & $* * *$ & 0.348 & $* *$ \\
\hline EG_0 siblings & 1.016 & & 0.774 & \\
\hline EG_1 sibling & 1.212 & $* *$ & 0.944 & \\
\hline EG_2 siblings & 1.418 & $* * *$ & 1.120 & $* *$ \\
\hline EG_3 and more siblings & 1.412 & $* * *$ & 0.989 & \\
\hline \multicolumn{5}{|l|}{ Divorce of parents } \\
\hline CR_separated & 1.348 & $* * *$ & 1.219 & \\
\hline CR_not-separated & ref. & & ref. & \\
\hline PL_separated & 0.639 & & 0.348 & $* *$ \\
\hline PL_not-separated & 0.588 & $* *$ & 0.303 & $* * *$ \\
\hline EG_separated & 1.484 & $* * *$ & 0.989 & \\
\hline EG_not-separated & 1.152 & $*$ & 0.821 & \\
\hline \multicolumn{5}{|l|}{ Education } \\
\hline CR_primary & 1.556 & $* * *$ & 1.528 & $* * *$ \\
\hline CR_secondary & ref. & & ref. & \\
\hline CR_tertiary & 0.502 & $* * *$ & 0.521 & $* * *$ \\
\hline PL_primary & 0.948 & $* * *$ & 1.361 & \\
\hline PL_secondary & 0.456 & & 0.665 & $* * *$ \\
\hline PL tertiary & 0.333 & $* * *$ & 0.348 & $* *$ \\
\hline EG_primary & 1.740 & & 1.922 & $* * *$ \\
\hline EG_secondary & 1.111 & $* * *$ & 1.514 & $* * *$ \\
\hline EG_tertiary & 0.707 & $* * *$ & 0.989 & \\
\hline
\end{tabular}

Note: $* \mathrm{p}<0.05 ; * * \mathrm{p}<0.01 ; * * \mathrm{p}<0.001$.

Model A 1-6 (Cox regression) - model of one explanatory variable. Model B (Cox regression) - model where all explanatory variables were included.

Source: Author calculation based on Czech, German and Polish FFS 1991-1997 data. 
The final results signify decreasing of statistical significance of particular variables which is the consequence of including all the variables in one model. Nevertheless, most of the variables in the Polish sample still had a statistically significant influence on decision about leaving parental home. The effect of the number of siblings remained quite strong in all three countries, even if another strong variableeducation-was included. One of the main results is the confirmation of previous outcomes; it is the fact that Polish women had the lowest risk of leaving parental home in comparison with Czech and East German women. For example, Czech women with secondary education were considered as the reference group in the final model. Polish women with secondary education had a 33 percent lower risk to leave home, while the East German women with secondary education had 51 percent higher relative risk of leaving parental home (see Table 8).

\section{Patterns of leaving parental home: synchronising and sequencing}

Not only timing reports the process of leaving parental home. There are also other approaches: sequencing and synchronising (see Billari 2001) that indicate the relationship among the events in the transition to adulthood. In the study, we are going to describe the relationship between leaving parental home (as the fundamental event) and the end of education, union formation, first marriage and birth of a first child. A new variable was created by comparing the timing of leaving parental home to the timing of other events. The variable signifies whether the other events have happened before, after or at the same time as leaving parental home. The aim of this part of the study is to try to find out if there is an influence of others events on the decision to leave parental home.

Some of the results are selected and presented below.

The first figure (Figure 5) represents the relationship between leaving parental home and the end of education. The distribution of these two events in the transition to adulthood is straightforward. Most of the interviewees left home after finishing their education. It was nearly $70 \%$ of East German and $80 \%$ of Czech and Polish women.

The second figure (Figure 6) shows relationship between leaving parental home and union formation. The distribution does not display so much heterogeneity between countries. It is obvious that most of the women left home at the same time as they started to live with their partners. The greatest differences are noted between East German and Czech women. More than one third of the East German women left home after union formation, while in the Czech Republic it was only $12 \%$.

The graph below (Figure 7) shows the relationship between leaving parental home and the first marriage. It is very interesting to compare Figure 6 and Figure 7. While in the Czech Republic and Poland there is hardly any difference between union formation and first marriage, there are quite distinct differences in East Germany. There is not so strong connection with union formation and marriage. While 
one half of East German women left home at the same time as they formed union, only $15 \%$ of them got married at the same time when they left home.

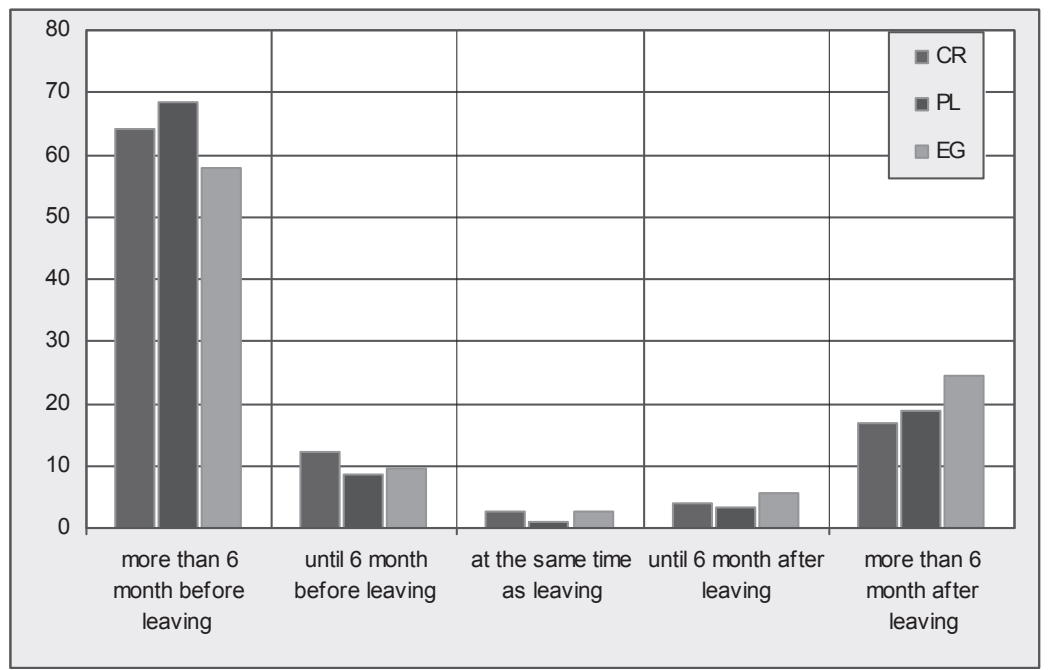

Fig. 5 Percentage of women that finished education before / at the same time / after leaving parental home in Poland, East Germany and the Czech Republic

Source: Author calculation based on Polish, Czech and German FFS data.

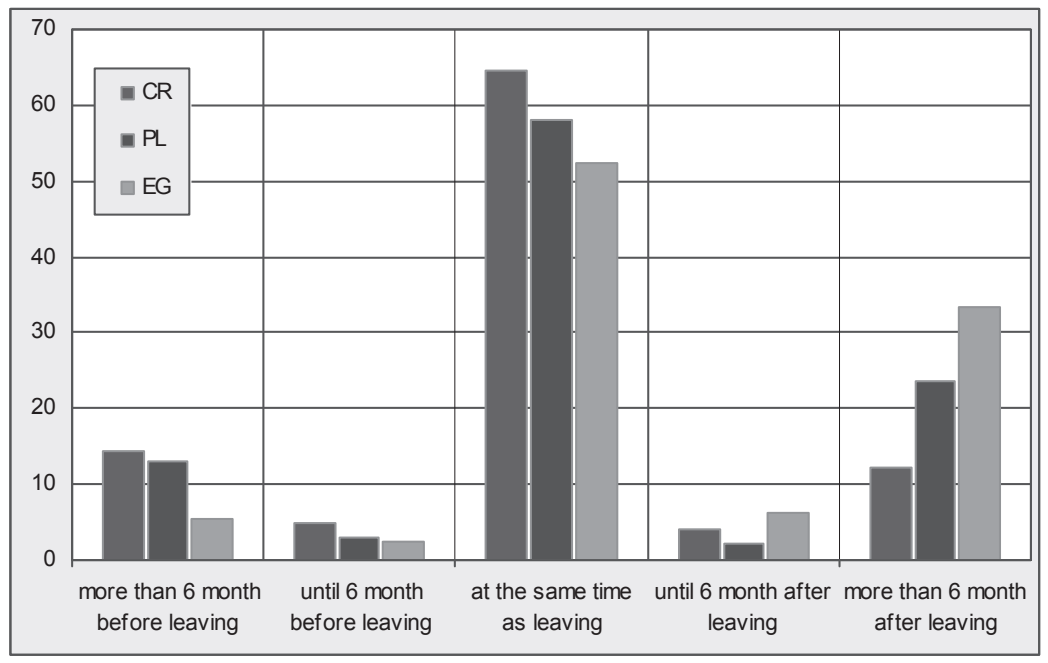

Fig. 6 Percentage of women that started to live with a partner before / at the same time / after leaving parental home in Poland, East Germany and the Czech Republic Source: Author calculation based on Polish, Czech and German FFS data. 


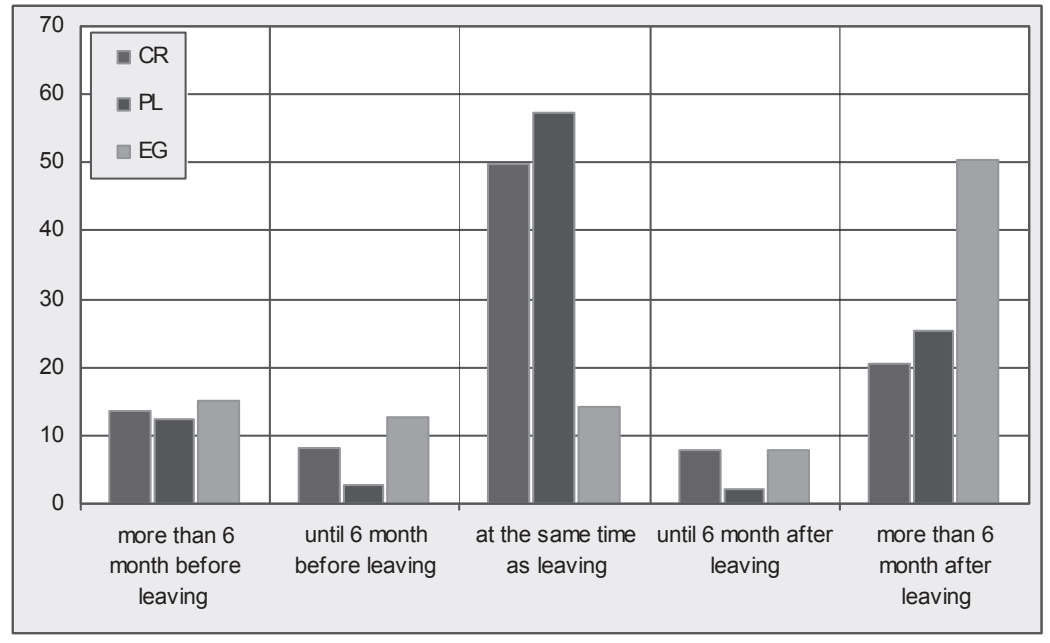

Fig. 7 Percentage of women that got married before / at the same time / after leaving parental home in Poland, East Germany and the Czech Republic

Source: Author calculation based on Polish, Czech and German FFS data.

\section{Conclusion}

The object of the study was the analysis of leaving parental home in connection with the transition to adulthood. For the purpose of the study three Central European countries were selected: the Czech Republic, Poland and former East Germany. I used data from Family and Fertility Survey that was conducted in 1991 (Poland), 1992 (Germany) and 1997 (Czech Republic). Women born in the period in 1952-1972/82 were interviewed.

The main aims of the study were first to analyse timing of leaving parental home in selected countries both separately and together and second to determine the sources of the main influence on interviewees' decision to leave parental home. The third aim was to study sequencing and synchronizing of certain events of transition to adulthood.

Information about the sample of women helped to characterize the situation in those countries at the time when the socio-economic development was to a certain extent governed politically without civil influence.

Both similarities and difference between countries were expected, but on the basis of the communist past not so much diversity in timing of leaving parental home was anticipated. I have obtained quite varied results. The greatest differences were found between the Czech and East German sample on one side and Polish sample on the other side. The timing of leaving parental home was generally delayed in Poland. On the contrary, East German women had the highest risk of leaving pa- 
rental home. In Poland the process was very heterogeneous by itself, while in the Czech Republic and East Germany it lasted for a shorter period of time. The strongest factors of leaving parental home in all three countries were number of siblings and education.

The approach of sequencing and synchronizing helped to look inside the process of transition to adulthood. It found out that in all three countries the event of leaving parental home very often happened in relationship with the formation of the first union. On the contrary, the relationship of leaving parental home and getting married was connected very strongly in the Czech Republic and in Poland, but it was not in East Germany. More than half of the women from East Germany got married at least six month after leaving parental home.

The results related to transition to adulthood were affected by socio-economic situation in those countries. The issue of housing policy very likely had a great influence on young people's life condition.

All the former communist countries experienced transformation of society in 90 's that led to considerable demographic and family patterns changes. Some of these aspects were evident in the Czech sample, where women from period 1952-1982 were interviewed. Results confirmed the delaying of leaving parental home in the birth cohort 1972-1982.

The Central and Eastern Europe definitely offer very fruitful area for further research, especially after the transformation of societies. New research is needed to capture all these large changes in demographic and family behaviour.

\section{Acknowledgements}

The support provided by the Ministry of Education, Youth and Sports of the Czech Republic, project no. MSM 0021620831 "Geographic Systems and Risk Processes in the Context of Global Change and European Integration" is gratefully acknowledged. This article is based on the master's thesis that was written while I was studying at the Faculty of Science, Charles University in Prague. For valuable comments and suggestions I especially thank my supervisor Jiřina Kocourková, next I would like to thank Anna Št’astná and Alena Černíková. I wish to thank the Population Activity Unit of the Economic Commission for Europe at the United Nations in Geneva for its permission to use the FFS data on which this study is based.

\section{References}

AASSVE, A., BILlARI, F. C., MAZUCCO, S., ONGARO, F. (2001): Leaving Home Ain't Easy: A comparative longitudinal analysis of ECHP data. MPIDR Working Paper WP 2001-038 [on-line]. December 2001 [cit. 2008-07-08]. Available from WWW: <http://www.demogr.mpg.de/>. 
BILLARI, F. C., LIEFBROER, A. C. (2000): Should I stay or should I go? The Impact of Age Norms on Leaving Home. Demography [on-line]. February 2007, vol. 44, no. 1, pp. 181-198 [cit. 2008-02-17]. Available from WWW: <http://www.ncbi.nlm.nih.gov/pubmed/17461342>.

BILLARI, F. C., PHILIPOV, D., BAIZÁN, P. (2001): Leaving home in Europe: the experience of cohorts born around 1960. MPIDR working paper WP 2001-014 [on-line]. May 2001 [cit. 2007-08-08]. Available from WWW: <http://www.demogr.mpg.de/Papers/Working/wp-2001-014.pdf >.

BILLARI, F. C. (2004): Becoming an Adult in Europe: A Macro (/Micro) - Demographic Perspective. Demographic Research [on-line]. April 2004, special collection 3, article 2, pp. 13-44 [cit. 2008-05-14]. Available from WWW: < http://www.demogr.mpg.de/>.

CORIJN, M., KLIJZING, E., BAIZAN, P. (2001): Transitions to Adulthood in Europe. Published by Springer, 2001, 340 s. Available from WWW: <http://books.google.com/books. ISBN 0792369653, 9780792369653.

FESTY, P., PRIOUX, F. (2002): An evaluation of the Fertility and Family Surveys Project. Paris: INED, 2002, p. 74.

HAMPLOVÁ, D., PIKÁlKOVÁ, S., RYCHTAŘíKOVÁ, J. (2001): “Diferenciace reprodukčního a rodinného chování v evropských populacich" ["Differentiation of Reproductive and Family Behaviour in the Populations of Europe"']. Sociological Papers 01:10, Praha: Sociologický ústav AV ČR.

HUININK, J., KONIETZKA, D. (2000): Leaving Parental Home in the Federal Republic of Germany and the GDR: The changing interrelation of leaving home and other transition events to adulthood [on-line]. Paper presented on the Workshop on "Leaving Home - A European Focus" 6.-8. September 2000. Rostock: Max Planck Institut for Demographic Research, $30 \mathrm{~s}$. Available from WWW: <http://www. demogr.mpg.de/>.

IACOVOU, M., BERTHOUD, R. (2001): Young People's Lives: A map of Europe. Colcester: University of Essen, Institute for Social and Economic Research, 2001, 64 s. ISBN 185871205 X.

JUANG, L. P., SILBEREISEN, R. K., WIESNER, M. (1999): Predictors of Leaving Home in Young Adults Raised in Germany: A Replication of a 1991 Study. Journal of Marriage and the Family [on-line]. May 1999, vol. 61, no. 2, pp. 505-515 [cit. 2007-06-21]. Available from WWW: < http://www.jstor.org/ $\mathrm{pss} / 353765>$.

SIENKIEWICZ, K. (2003): Leaving Parental Home in Poland. Rostock: Max Planck Institute for Demographic Research [on-line]. 2003 [cit. 2008-01-08]. Available from WWW: <http://paa2004. princeton.edu/download. asp?submissionId $=41498>$.

VERMUNT, J. K., MOORS, G.: Event history analysis [on-line]. Department of Methodology and Statistics, Tilburg University [cit. 2007-10-26]. Available from WWW: <http://spitswww.uvt.nl/ vermunt/ esbs2005b.pdf>.

WHITE, L. (1994): Coresidence and Leaving Home: Young Adults and Thein Parents. Annual Review of Sociology [on-line]. 1994, vol. 20, pp. 81-102 [cit. 2008-05-22]. Available from WWW: <http://www. jstor.org/pss/2083360/>.

WHITE, L., LACY, N. (1997): The Effects of Age at Home Leaving and Pathways from Home on Educational Attainment. Journal of Marriage and the Family [on-line]. November 1997, vol. 59, no. 4, pp. 982-995 [cit. 2008-01-03]. Available from WWW: <http://www.jstor.org/pss/353797/>.

\section{Résumé}

\section{Přechod do dospělosti: Odchod dětí z domova rodičů ve vybraných zemích stř̌ední Evropy}

Cílem tohoto článku bylo postihnout problematiku přechodu do dospělosti, potažmo proces odchodu dětí z domova rodičủ ve vybraných zemích střední Evropy. Pro analýzu byla použita data z mezinárodního šetření Fertility and Family Survey, konkrétně se jednalo o ženy narozené v období 1952-1972/82. Země Česká republika, Polsko a Východní Německo byly vybrány záměrně. Tyto země po dlouho dobu 40 let zaživaly shodný politický systém. Na druhou stranu měla každá z vybraných zemí odlišný historický vývoj. Hlavním cílem bylo na základě výše zmíněných faktorů nalézt shody a odlišnosti v časování odchodu z domova rodičc̊. Mezi nejvýznamnější zjištění náleží zaprvé to, že v Polsku dochází k odchodu od rodičů později a že přibližně jedna třetina žen neodešla vůbec $\mathrm{z}$ domova rodičů. Naopak ve Východním Německu ženy odcházely $\mathrm{z}$ domova rodičů $\mathrm{v}$ mladším věku. Tato událost byla ve Východním Německu částečně propojena s další udá- 
lostí přechodu do dospělosti, s prvním soužitím s partnerem, avšak nesouvisela do takové míry s uzavřením manželství. Pro český vzorek žen bylo naopak typické, že odcházely z domova relativně brzy po dosažení plnoletosti. Událost odchodu od rodičů byla však výrazně spjata s prvním soužitím s partnerem a zároveň s manželstvím. U všech třech souborů žen bylo zjištěno, že počet sourozenců a vzdělání v době odchodu dětí od rodičů byly faktory se silným vlivem na odchod dětí od rodičů.

Lucie Kynčilová

Charles University in Prague

Faculty of Science

Department of Demography and Geography

Albertov 6

12843 Prague 2

Czech Republic

e-mail: lukyncilova@gmail.com

phone: + 420607875590 